\title{
Migration of Senegalese fishers: a case for regional approach to management
}

\author{
Thomas Binet*, Pierre Failler and Andy Thorpe
}

\author{
* Correspondence: thomas.binet@ \\ port.ac.uk \\ CEMARE, University of Portsmouth, \\ St George's Building, 141 High \\ Street, Portsmouth, PO1 2HY, United \\ Kingdom
}

\begin{abstract}
This article traces the recent history of Senegalese small-scale fishers' migration in West Africa. It details how migration of Senegalese fishers developed and then intensified to become a specialized fishing strategy spread out all along the coast of West Africa, from Mauritania to Sierra Leone and beyond. This escalation has rapidly led to the depletion of fish stocks in the region. Today, while fishing migration still largely contributes to food security and provision of sustainable livelihood for coastal communities, this type of migration has reached both an ecological and social deadlock and its future is largely uncertain. Based on current trends in Senegalese fishing migration, this paper highlights the main drivers of changes and impacts of migration. It proposes the development of a regional approach to fisheries management, emphasizing the need for collaborative transnational research projects and stressing the necessity for biodiversity project managers to include the issue of fisheries migration in their regional conservation strategies. It also suggests there may be a need to introduce property rights so as to limit the open access enjoyed by Senegalese migrant fishers almost all over the West African sub-region.
\end{abstract}

\section{Introduction}

The fisheries sector in West African countries is of paramount importance as a critical source of economic, social, environmental and cultural value for West Africa's growing population of almost 300 million people: fisheries can represent up to $15 \%$ of national Gross Domestic Product and up to 30\% of export revenues, employs around 7 million people and provides up to 50 of total animal protein intake of the region's population while sustaining local livelihoods for coastal communities (Binet 2008). More than 70\% of the fish production in the region comes from artisanal fishers, Senegalese and Ghanaian fishers being the most active groups along the regional coastline, from Mauritania to Sierra Leone. A major part of the artisanal fishing activities are carried out through long-distance fishing migration across the seven member States of the Sub-Regional Fishery Commission (see Figure 1 below for a map of the sub-region). Fishing migration is therefore an essential element of artisanal fisheries in West Africa (Haakonsen 1991; Chaboud and Kébé, 1991; Chauveau 1983, 1991).

In the 1990s, at a time when the region served growing global demand while trying to develop an economically viable fisheries sector at home, a general overexploitation of fish stocks has been highlighted (Failler and Gascuel 2008). This overexploitation has become even more pronounced recently (Ibid). This begged the question as to how

\section{Springer}

(c) 2012 Binet et al.; licensee Springer. This is an Open Access article distributed under the terms of the Creative Commons Attribution License (http://creativecommons.org/licenses/by/2.0), which permits unrestricted use, distribution, and reproduction in any medium, provided the original work is properly cited. 


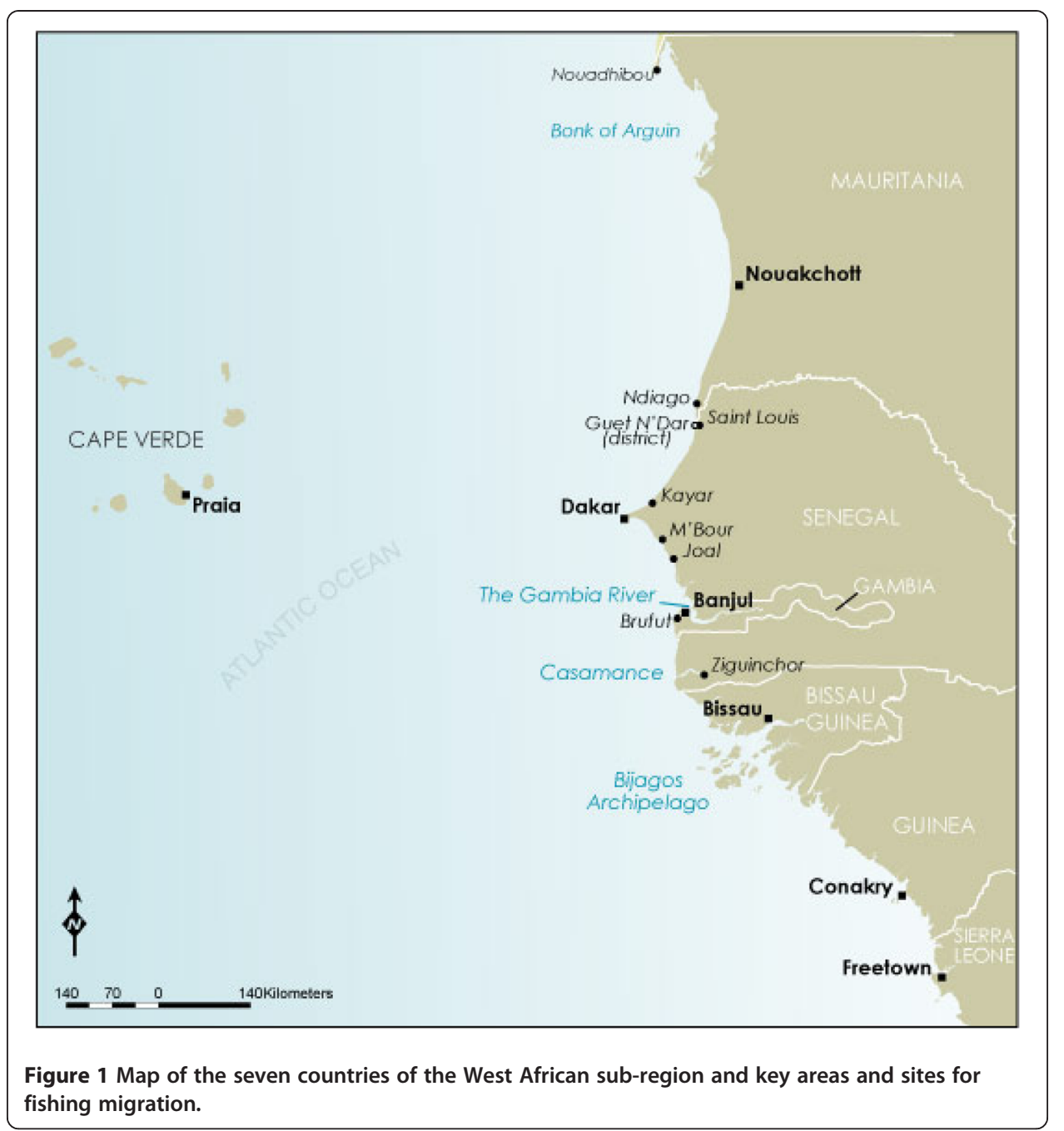

long would fish resources be able to sustain intensive small-scale fishing and especially activities of migratory Senegalese fishers and others? The limited attempts to date by national authorities to control this phenomenon (including, for instance, the limitation of fishing licenses given to foreign fishers), are undermined by both fishers circumventing these controls - and the limited enforcement capability of the authorities over such large marine areas. As a result, while migrants continue to operate furtively and far from capitals, this phenomenon of fisher migration, which has remained ignored over the past two decades, has very recently attracted the interest of national policymakers in West African countries. But is it not too late to take steps towards better management of this issue?

This article aims to provide a review of the evolution of migratory processes by smallscale fishers along the coasts of West Africa in the past, and more particularly over the last three decades. The paper also intends to give some further evidence on the need for strong management action as migration - migration of Senegalese fishers in the first instance - has largely contributed to a generalized depletion of fish stocks within the whole West African region. The first section of the paper documents the development of the artisanal fisheries sector over the past and explains why fishing migrations have 
thrived since the 1970s. In the second part we link the development of fisheries to fisher migration trends and show how migration has evolved to adapt to the overexploitation of local fish stocks. The third part presents the migration trends and gives further information on Senegalese migrants' strategies. The fourth part explores the reasons why West African fisheries have reached an ecological and social deadlock. The article concludes by providing insights on the future of migration and the alternatives for migrant fishers before suggesting policymakers recognise the importance of fishing migration and accept the need to move towards a regional fisheries management framework. The choice was made in this paper to focus on Senegalese fishers as these, along with Ghanaian fishers, are the most important in terms of the numbers involved.

\section{Research and method}

Jorion (1988) has defined the migration of fishers as a dual phenomenon that covers both the seasonal movements that repeat from one year to the next, and long-distance movements that lead to the settlement of the migrant in a region or a country for a longer-lasting period. As this definition appears as too broad when applied to Senegalese fishers, the authors have developed a specific definition for their study. Thus, this paper here considers fisher migration as: the movements of groups of fishers that follow a migratory pattern including a return to their community of origin after one or several years; these movements could be multiple and combine several fishing strategies, and deploying over a minimum period of one week and at a distance of 30 nautical miles away from their origin community. These timing patterns and scales are analogous to typology of West African migration described by Randall (2005).

The data provided in this paper come from both an extensive literature review on the subject of Senegalese migratory fishers in West Africa and field research conducted during the period 2007-2009 in Senegal and along the coast of West Africa, from Mauritania to Sierra Leone. The demographic literature on migrating fishermen is very poor: migrant fishers do not fall into the major categories of interests in demographic studies, such as rural-urban migration and trans-continental migration (Randall 2005). The fishery literature on fishermen migration in West Africa is also limited and the impacts of migrant fishers on the marine environment (and vice-versa) have been neglected. In contrast, such issues have received substantial attention in other countries worldwide, such as Chile (Aburto et al. 2009), Ecuador (Bremner and Perez 2002), Papua New Guinea (Cinner 2009), Indonesia (Cassels 2006; Kramer et al. 2002), Madagascar (Cripps 2009) and in eastern Africa (Crona and Rosendo 2011). Only social science disciplines have shown an interest in the migration of West African fishers, with a number of key publications on sociological dimensions of seasonal movements of fishermen appearing in the 1970s and 1980s (Binet 1973; Chauveau 1986; Jorion 1988; Nguyen Van Chi-Bonnardel 1980). This sociological attention dropped off significantly in the 1990s, despite two major workshops which discussed migration. ${ }^{\text {a }}$ More recently, in the early 2000s, the Sustainable Fisheries Livelihoods Programme embracing 28 West African countries focused on migration as (one of the) strategies that fishing communities often use in order to secure their livelihoods (Njock and Westlund 2010).

More recently, the migration issue has been the subject of renewed interest for two main reasons. First, in recognition of the major economic and social threats occasioned by the generalized overexploitation of fish stocks, and the notion of migration being a 
response to environmental pressures - urgent need to update knowledge on migrating fishers in order to inform national and regional decision prompting the need for urgent governance decisions (Warner 2010). Second, since fisheries are the major contributing sector to the illegal migration to Europe (Sall 2007). There is therefore an -making and improve policy coherence in development and environmental conservation spheres in the West Africa region.

Field research in the destination countries of Senegalese fishers was conducted based on a double investigation. First, collaborative work with national fisheries research centres in Senegal and in the six countries of the study led to the documentation of each migratory movement. Information was collected through interviews with national researchers who are experts on the issue of fishing migration. For each migratory movement, information was sought from these experts on the following: migrant ethnic group, recent history of migration and trends, details on fishing production (for example targeted species, type of fishing boat, fishing technique, annual catch per boat, mean value of catch), details on the value chain (landing site, final country of destination, processing), organisational aspects of migration (for example means of financing of production, organization among production units, supply of food and material when at sea, hiring of crew), institutional aspects (for example access rights, licences), and the nature of, and relations between local and migrant fishers. Second, research revolved around semi-directed interviews in the main sites of departure for Senegalese migrant fishers (Saint-Louis, Gandiole, Dakar, the Petite Côte, Casamance et cetera. - see Figure 1 for map of main sites of departure). In each of the major regional landing sites (ten sites in total), four interviews were conducted with key stakeholders (such as fishers, local representatives, fishmongers and fish processers) to allow us to corroborate the information gathered from experts.

The same method was also deployed in destination countries of the sub-region (that is Mauritania, the Gambia, Guinea-Bissau, Guinea, Sierra Leone): data collection among experts drawn from national fisheries research centres and semi-directed interviews with representatives of fishers (both local and migrant) in fishing camps where Senegalese fishers have been spotted over the past three decades. Five major national landing sites were studied in each country.

Field research thus enabled us to cross-check the collected information by comparing findings from at least two different independent sources, thus substantially increasing the accuracy of the data provided in this paper.

\section{The development of migratory fishing and subsequent overexploitation of stocks}

As far back as the sixteenth century, sailors were reported to go out to sea on board pirogues in order to not only fish for their own food, but also for trade or military purposes (Chauveau 1986). With the adoption of sail at the beginning of the seventeenth century, African fishers have fished sometimes far from their home shore, following the migratory movements of fish as they move to spawn in certain areas. At the end of the nineteenth century, migration of Senegalese fishers extended across the whole sub-region, from Mauritania to Sierra Leone (Chauveau 1991; Gruvel 1908). At this time, many West African countries relied on the export of primary products (Arabic gum and palm trees products, peanuts, rubber production, coffee and cocoa) supplemented by an 'informal' economy which saw trade between small holders in rural areas and the urban centres located on 
the Atlantic coast. ${ }^{\mathrm{b}}$ As the informal economy grew, small-scale fisheries also benefited and gradually switched from subsistence fishing based on in-kind transactions to artisanal activities for commercial purposes (Nguyen Van Chi-Bonnardel 1980). New outlets for exports also acted as a catalytic factor and migration increased in search of higher value species (such as grouper, sole or meagre) with European processing and export industries in the 1940s and 1950s essentially reliant upon small-scale migrant Senegalese fishers for their import supply.

Thanks to technological progress, the geographical fishing range of migrants (most notably the Ghanaians and Senegalese) has grown since the 1950s, with many now only periodically returning to their villages of origin. This was possible as, in neighbouring countries such as Guinea-Bissau, Sierra Leone and Liberia, fisheries were still underexploited and thus resources were much more plentiful. The major 'push' factor to the development of fisheries in Senegal has been the repeated droughts experienced by farmers during the 1970s (Tricart 1993). These droughts caused substantial rural flight, and marked the end of cash crop farming as a driver of the Senegalese economy. The fisheries sector was the most welcoming economic sector, with the fisher population multiplying three to four times within a decade.

The massive growth of the domestic fisheries sector, and the subsequent adoption of transnational migration as a strategy for increasing catches was enabled by three main conditions. First, national development programmes and donor support provided pirogues and fishing gear at low cost to new entrants. Programmes dating from the 1950s supported fleet motorisation, and by the 1970s, more than ninety per cent of the artisanal Senegalese fishing fleet was motorised (Sall and Morand 2008). Second, this motorization allowed both new and established fishers to quickly access new fishing grounds and, coupled with the development of new fishing techniques such as the drifting gillnets or the use of onboard ice box, this enabled fishers to increase their productivity. Third, the expansion of export markets following the Yaoundé (1963) and Lomé (1965) Conventions, which offered preferential access to European markets for primary products [including fish] originating in the forty seven ACP countries, saw fishers migrate in pursuit of high value species, the task of catching low value species being progressively delegated to non-motorized pirogues and subsistence fishing for the local markets. Senegal became one of the main exporters of raw and processed fish products to Europe - through both European processing industries located in West Africa and the export of raw material to national markets such as Rungis in Paris and the Puerto de Toledo market in Madrid.

\section{The emergence of a new form of fishing migration}

The 1980s mark a turning point in the development of the fisheries sector and the related fishing migration of Senegalese fishers. Historically, migrant fishing had occurred upon a local seasonal cycle, punctuated by an annual return to the home village located in one of the main three departure regions of the country (Saint Louis in the north of Senegal, the Dakar peninsula and the Petite Côte south of Dakar, and from the Siné-Saloum delta). Migrants tended to return to their homes during the annual rice planting and harvest seasons, subsequently undertaking what (Cormier-Salem 1995, 2000) calls 'route' fishing - the route being punctuated with stops in coastal cities where catches are landed.

By the 1980s, the main commercial stocks were showing signs of depletion under the continuous pressure of fishers, both migrant and local, not only in the Senegalese 
Table 1 Evolution of catches and exploitation levels of main commercial species (Failler and Gascuel 2008)

\begin{tabular}{|c|c|c|c|}
\hline Species & Fleets* & $\begin{array}{l}\text { Catches between } \\
1997 \text { and } 2006\end{array}$ & Exploitation level \\
\hline $\begin{array}{l}\text { Demersal species } \\
\text { (grouper, meagre, sole, etc.) }\end{array}$ & CV, Gui, Ma, Mo, Sen, Sp & $-26 \%$ & $\begin{array}{l}\text { Moderate to intense } \\
\text { over-fishing }\end{array}$ \\
\hline $\begin{array}{l}\text { Cephalopods (octopus, squid, } \\
\text { cuttlefish, etc.) }\end{array}$ & Ma, Mo, Sen, Sp & $-31 \%$ & $\begin{array}{l}\text { Moderate to intense } \\
\text { over-fishing }\end{array}$ \\
\hline $\begin{array}{l}\text { Small pelagic species } \\
\text { (sardines, sardinellas, ethmalose, etc.) }\end{array}$ & CV, Mo, PB, Sen, Sp, Ukr & $-20 \%$ & $\begin{array}{l}\text { Full exploitation and } \\
\text { moderate over-fishing }\end{array}$ \\
\hline Crustaceans (lobster, crab, shrimp, etc.) & $\mathrm{Fr}, \mathrm{It}, \mathrm{Mo}, \mathrm{Sen}, \mathrm{Sp}$ & $-38 \%$ & Full exploitation \\
\hline
\end{tabular}

* CV Capo Verde, Fr France, Gui Guinea, It Italy, Ma Mauritania, Mo Morocco, Neth Netherlands, Sen Senegal, Sp Spain, Ukr Ukraine.

Exclusive Economic Zone (EEZ) but also in adjacent foreign waters. Long-distance industrial foreign fleets operating under fisheries access agreements also saw catches decline by between twenty to forty per cent between 1996 and 2007 (see Table 1 below). What was true for West Africa was even worse for Senegal, with grouper stocks experiencing an eighty per cent drop in population in the decade to 2000, as fishing exploitation in the region went far beyond the biological threshold (Dahou and Deme 2002).

In the context of growing resource scarcity, Senegalese migrant fishers had no other choice but to extend their migration area and exploit new stocks (Bakhayokho and Kébé 1991). This option was possible due to:

- The very high prices for high-value species on the export market (Kébé 1993);

- Unexploited fishing zones (as in the case of the Bijagos Archipelago in GuineaBissau or the isles of Tristao and Alcatras in Guinea, where fishing was largely still for subsistence purposes); and

- The lack of controls and regulation over such fishing, despite the creation of EEZs after the third United Nations Conference of the Law of the Sea (1983), when formal access to foreign EEZs was then subject to licenses (as opposed to formerly when local arrangements could be made with traditional local authorities).

Progressively, a new form of migration emerged. The seasonal character of migration faded, as did journeys to the home villages during the rainy season. Now at sea all year long, migrant fishers forsake a permanent home for year-long 'temporary' habitation close to their current fishing grounds. Mostly composed of very young men, these migrants are motivated by the desire for monetary gain, a desire which is strong enough to keep them living in bad conditions and far from their home almost all year (Odotei 1991; Overa 2000). In other words, the migration scenario causes them to suspend the tradition of regularly returning home with revenues for their families.

This change from seasonal part-time movement (when fishing was practiced as a parttime activity) to long-term migration (when fishing is a full-time job) is of particular importance in the history of fishing in West Africa. For Jorion (1988), this is the time when fishing migration become a forced migration because of environmental change. For him, there is a difference between seasonal movements and fishing migration per se. He says that:

'[B]ecoming a full-time fisherman (when one has been a part-time one) is never a voluntary choice. It is something one has been forced into doing by adverse circumstances. One may ... consider it as a universal sociological law that no one becomes a full-time maritime fisherman other than under duress'. 
This statement has since been criticised by work on non-economic satisfaction in fisheries that suggests that fishing could result from a deliberate choice rather than the obligation to sustain livelihood. Such conclusions were demonstrated in Alaskan fisheries (Pollnac and Poggie 2006) and in the Caribbean (Monnereau et al. 2010) and by work on livelihood diversification and vulnerability to environmental changes (Cinner and Bodin 2010; Coulthard 2008).

Two organisational changes have contributed to the permanent establishment of fishers in foreign EEZs. The first relates to the development of fisher camps in destination countries. Here, the provision of fuel and ice is no longer organized from the home landing sites in Senegal, but directly at the new landing sites that have been established in the host countries. Some of these landing sites have been built with the help of international co-operation projects in areas close to important fishing zones (such as on the isle of Canhabaque in the Bijagos Archipelago, Guinea-Bissau). In most cases, these landing sites are also permanent camps where fishers may settle down. Equipped with several units for processing (smoking and drying) of low-value essentially small pelagic species, camps are (in a sense) economic enclaves linked with the migrants' origin country -operating continuous back-and-forth transportation of fish in pirogues (which can ship a maximum of thirty tons per trip). The return pirogue trip imports fuel, food, and fishing gears into the camp.

The second form of migration is less visible since fishers never disembark from their pirogues, yet it is of major economic importance, responsible for sixty per cent of fish export volumes, some 80,000 tonnes annually, to the EU (Binet and Failler 2011). It is estimated that over 15,000 Senegalese fishers (30\% of the total national labour force in the sector) have left their homes and simply sailed into foreign waters on short fishing trips (Ibid). Trips last a maximum of ten days (the maximum time for conservation of fish in ice), and is undertaken jointly by two similar pirogues with the same stocking capacity, same speed, and same number of crew. In the case of ports set on the Petite Côte (M'bour, and Joal) toward the Bijagos Archipelago, the pirogues take two days to reach the fishing grounds, and then spend six days setting and hauling nets, before returning to the home landing sites in Senegal with more than six tons of thiofs (groupers), red snappers and sea bream in the hold. This process can goes on for the whole year.

Also, since the mid-1990s, a third organisational change has emerged, where (tens of) pirogues are subcontracted to catch fish on behalf of industrial vessels. This reported technique of pêche au ramassage is apparently quite common between Korean trawlers and Senegalese pirogues from Saint-Louis (Mathew 2010). The trawlers can take onboard as many as 40 pirogues and their crews. They charter them down to GuineaBissau but sometimes as far as Gabon and serve as a floating basis - a mother ship for the pirogues that fish for them (Sharp 1994). However, there is very little information available on this strategy that deploy offshore and few fishers have mentioned this during field research.

Accompanying these developments, there have also been changes in the targeting of certain species. For instance, while shark fishing had been practiced for decades in West Africa, the activity intensified greatly in the 1990s driven by the demands of the Asian market where shark fins are sold at up to 350 Euros per kilogram. The localised expansion of shark fishing was, however, limited by the physiological limits of selacian stocks (which are characterized by a long life cycle and a very limited renewing of spawning 
stock biomass), and saw Senegalese shark fishers turn to Gambian, Bissau-Guinean, Guinean and Leonese waters in order to sustain production levels.

From an economic perspective, estimates currently suggest that almost 100,000 tonnes of fish are harvested annually by Senegalese migrants in foreign EEZs - compared to a volume of about 400,000 tonnes of domestic catches (Binet and Failler 2011). This is considerably higher than the aggregate catches of artisanal fishers in 1965, which amounted 80,000 tonnes (Chaboud and Kébé 1991), and the 150,000 tonnes recorded in 1981 (Deme and Barry 2005). Though the literature does not provide any estimate of the proportion of foreign catches landed as part of these domestic catches, research interviews suggest this proportion may account for less than $10 \%$ of the total catch.

From a spatial perspective, fishers increasingly sail outside the frontiers of Senegal to exploit more abundant fishing grounds. Until the 1980s, Senegalese fishers were mostly fishing in Senegalese waters (mainland and Casamance region), with only a small percentage migrating to foreign waters. During the 1980s, Senegalese fishers practiced seasonal migration, but largely directed to domestic waters: Grande Côte (Kayar) and Petite Côte (Joal Fadiouth, M'Bour), Casamance region (Kafountine, Boucotte), Siné-Saloum (Missirah) and Dakar peninsula (Yoff and Soumbedioune) (Chaboud and Kébé 1991). Migration to the neighbouring countries of Mauritania (exclusively from Saint-Louis), the Gambia, GuineaBissau and Guinea (Chaboud et al. 1988), and Sierra Leone largely dates from the beginning of the 1990s.

Figure 2 below provides further information on migrant movements across the subregion. In the case of Wolof fishers from the suburbs of Guet N'dar (identified by the code GD on the map) and Gandiole (coded G on the map) in the region of Saint Louis, these migrations now extend towards:

- Mauritania from the Saint-Louis region (see flow coded GD1 on the map 1);

- he Petite Côte, the Gambia and Casamance from Guet N'dar and Gandiole (GD2, G1);

- The Bijagos Archipelago, south Guinea-Bissau and north of Guinea from the Petite Côte (GD3, G2); and

- Guinea and Sierra Leone from Guinea-Bissau (GD4, G3).

Lébou fishers originating from the region of Dakar migrate southwards:

- Towards the Petite Côte from the Dakar peninsula (Lé1) where they have set up permanent habitations

- To the Gambia and Casamance (Lé2);

- To the Bijagos Archipelago, south Guinea-Bissau and north of Guinea, directly from the Dakar peninsula and from the Petite Côte (Lé3); and

- To Guinea, Sierra Leone and further south to Libéria, directly from the Dakar peninsula and from the Petite Côte (Lé4).

The Nyominka fishers originating from the Saloum delta (Ny on the map) migrate to the Petite Côte (Ny2) where they can find outlets for their production. They also migrate southward to:

- The Gambia and Casamance (Ny1) from the delta of Saloum and Petite Côte;

- Guinea-Bissau and Guinea (Ny3) from Casamance; and

- Guinea and further south to Sierra Leone and Liberia from the Bijagos Archipelago (Ny5).

Also, albeit to a lesser extent, the Diola fishers from Casamance (coded as Di on the map and table) migrate to the south to Guinea Bissau (Di1) and also to the Gambia (Di2). 


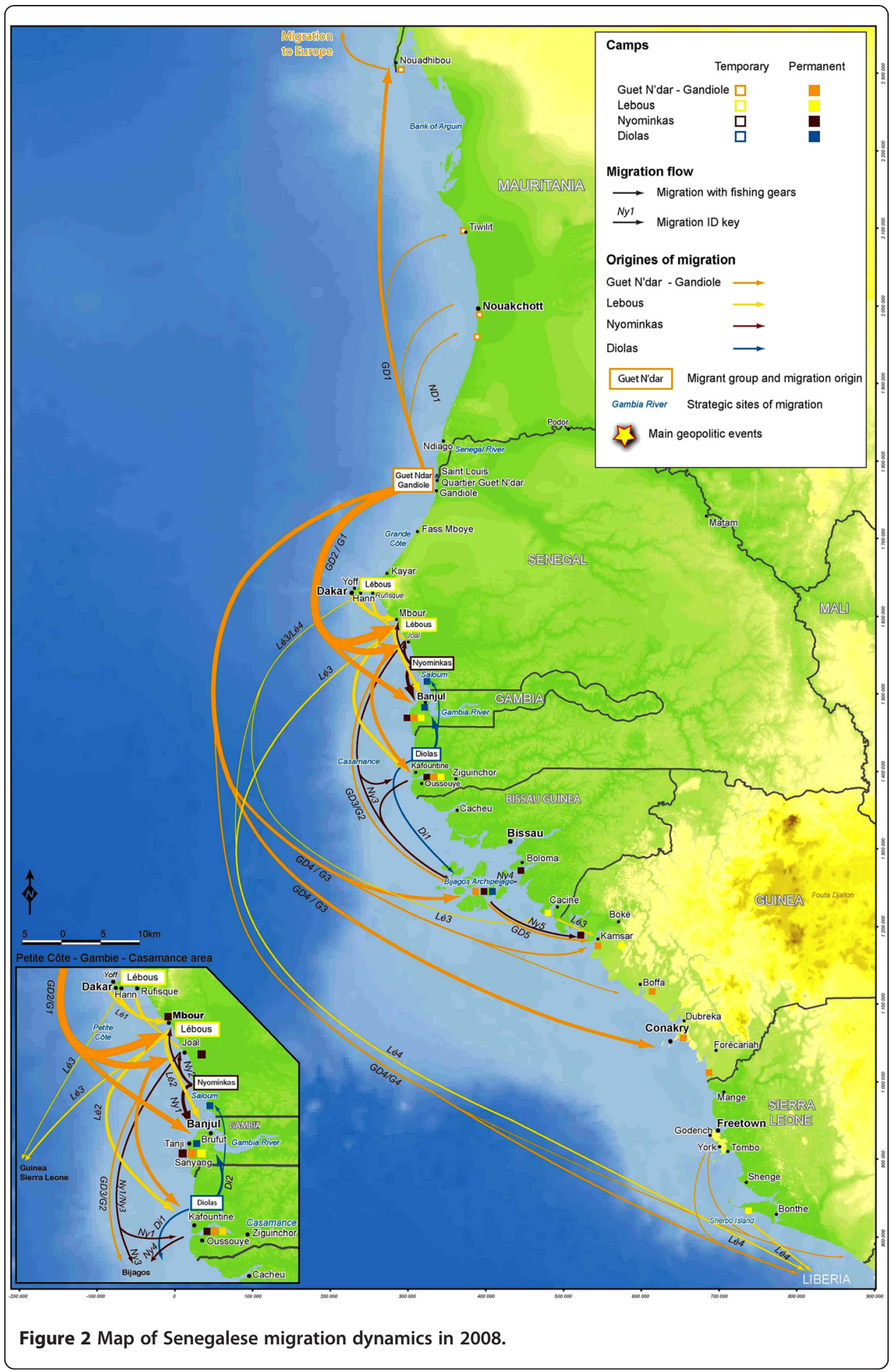

\section{Future of migration and the regional approach to management}

Regarding the situation described above, one can wonder about the sustainability of fisheries in the region if nothing is done to limit their impacts. The migrant fishers will have only two alternatives to fishing: first, to migrate into evermore remote areas in search of fish; second, to intensify their fishing activities in already overexploited zones, 
using more efficient - and destructive - techniques, or turning towards new underexploited species (if they exist). The first alternative will force them to undertake ever longer journeys, sometimes leading to a life spent onboard pirogues. The second alternative is no better: increasing operational costs due to more intense efforts to catch scarcer and smaller fish (and perhaps more illegal fishing conducted in protected areas or using banned techniques).

Other fishers have already adopted a third alternative and turned towards illegal migration to Europe. Migration via maritime routes has largely increased since the closing of the Spanish landlocks in Morocco: with hundreds of fishing boats leaving Senegal or Mauritania for the destination of Canary islands each year. Fishers not only organize this illegal transport but also migrate themselves to the Canaries, with the Senegalese government receiving European funds so as to establish rural development programmes in Senegal to re-integrate young migrants who have been repatriated back to Senegal (Dahou 2008).

The three key problems relating to the impacts of migration on West African ecological and social systems revolve around the fact that: 1) the extent of fisher migration remains largely unknown and unmonitored; 2) migrants often fish illegally or in unregulated areas; and 3) migration is increasingly causing conflicts between fishers (local and migrant).

First, most of the catches by these migrant fleets are neither known, nor accounted for, in national statistics as landings do not always take place in the country from where the migrants originates, and/or landing sites are too remote to be covered by national fisheries surveys (Laloë 2007). Where catches are monitored, the fishing location is not noted - and catches are automatically treated as being domestic catches. Consequently, while statistical data in the area where the catch occurs is/are understated, national statistics in the migrants' home countries are skewed by this artificial increase in production accruing from foreign EEZs. This not only gives misleading catch data (vis-à-vis catch origin), but also makes it very difficult to provide accurate scientific advice on the status of stocks - and hence inhibits the development of effective management plans. Regional co-operation for research thus appears to be an essential primary step to the improvement of migration monitoring. Hence, national research institutes should cooperate and share data at a regional level in order to precisely quantify the number of migrants, the catch volumes crossing borders, and the proportion of unofficial foreign catches in the statistics of total "domestic" landings.

Second, fishing migration leads to illegal practices. Since the recognition of national EEZs, nations with a migrant fisher population have been obliged to establish official fisheries access agreements with destination countries if they want to go on fishing in richer foreign waters. These official agreements replace informal agreements where access was often granted by traditional village chiefs to migrant fishers in exchange for small services and gifts. The current official agreements generally set the total number of pirogues allowed to fish in foreign EEZs, although levels of total allowable catch or limitations on the harvesting of certain species are not specified. However, thanks to the very limited maritime control capacity and widespread corruption, illegal access has developed and the number of migrants' pirogues can often exceed the total authorized. This illegal fishing also occurs in Marine Protected Areas (MPA), where migrants benefit from poor enforcement of management measures. This fishing is particularly 
damaging for the marine environment since it is concentrated in ecologically significant areas, be it in Biosphere Reserves (such as in the Bijagos Archipelago, or to lesser extent in the Park of Banc d'Arguin) or in an MPA which is in the process of being created (for example Tristao and Alcatras MPA in Guinea). Here, migrant fishers activities totally undermine biodiversity protection and marine ecosystem conservation.

Third, the combination of environmental degradation and migration created a potential for violent conflicts (Odotei 1991; Surhke 1992). As activities of migrant fishers are increasingly conducted in traditional fishing zones of local communities, this decreases the catches of local the population and can, in extremis, force them to leave their historical fishing ground (Failler et al. 2009). Consequently, in spite of the contribution of migrant fishers to the economic and social development of the local communities where the migrants are installed (for example, the creation of jobs, sources of revenues, exchanges between local and migrant communities), there are an increasing number of conflicts between local and migrant populations, conflicts which can lead to a rejection of migrants, and their expulsion from the host villages. In terms of rebutting controls imposed on their fishing activities or resolving the conflicts that may arise with local populations, migrant populations often have no rights. It is therefore necessary for migrant fishers to first legitimise their presence in foreign waters in order to benefit from rights in these countries. Again, a strengthened regional fisheries management institution may contribute to this recognition and to the development of an integrated regional framework that could tackle the migration issue and help with the resolution of conflicts.

As a result, the 'fisher migration' issue is very much a challenge at the regional scale for both the conservation of marine ecosystems in MPAs and the regulatory framework for fisheries management. To this end, national decision-makers should firstly take action to limit the impact of fishing migration in ecologically sensitive areas, on already threatened species (for example sharks, rays, demersal fish) and on accidental catches (for example turtles, cetaceans). This could involve the strengthening of regional cooperation in fisheries management through the empowerment of regional fisheries management bodies such as the Sub-Regional Commission for Fisheries (SRCF). Biodiversity conservation bodies also have a role to play with regards to this issue. Marine conservation projects currently benefit from substantial sources of funding originating from foundations, international organizations and bilateral donor funding. However, these projects often deal with emblematic biodiversity and focus upon local communities within the limits of the defined MPA, ignoring migrant fishers in the neighbourhood whose activities are potentially one of the primary threats to the functioning of local marine ecosystems. Hence, fisher migration should not only be addressed within fisheries management policies, but also as part of marine conservation strategies in regional biodiversity projects.

Furthermore, the issue of regional property rights for migrant fishers should be particularly addressed. The establishment of property rights governing the exploitation of marine resources, even in complex multi-attribute and large scale fisheries, has proved to be essential to maintain fish stocks within safe biological limits (Edwards 2005; Costello and Kaffine 2008). In Chile, the introduction of property rights over resources has had very positive impacts, including the prevention of stocks being overexploited by migrant fishers from various regions of the country (Gelcich et al. 2010). In addition to 
the creation of property rights for migrants, co-management and inclusive governance could also be further explored as a complementary approach to counterbalance overfishing (Njock and Westlund 2010; Cinner et al. 2009). However, there are obstacles to the implementation of regional-scale property rights over migrant fishing activities in West Africa. These include: the potential loss of sovereignty of national governments in front of international initiatives directed at the issue (which can weaken the role of governments in national fisheries management processes, thereby undermining long-term resource sustainability objectives); a lack of clarity in regional fisheries governance issues due to the superimposition of new international initiatives (Trouillet et al. 2011) over existing governance mechanisms (ie; national EEZs, the regional Large Marine Ecosystem project, as well the sub-divisions of the FAO Fishery Committee for the Eastern Central Atlantic - CECAF); while the weakness of West African governments in the fisheries management domain may prevent moves towards co-management regimes, since national authorities must be able to effect any agreed management regime/measure (Pomeroy and Berkes 1997).

\section{Conclusions}

This article examines the recent history of Senegalese small-scale fishers' migration in West Africa. It details how migration of Senegalese fishers has now become one of the major factors of the overexploitation of fish stocks in the whole sub-region, and suggests that the future of West African fisheries faces both an ecological and social deadlock if this issue is not addressed. We identify three key issues that need to be addressed - the informational deficit that presently exists (notwithstanding the contribution of this paper) relating to the activities of migrant fishers in the region, the legality of such fishing activities (in terms of both marine spaces accessed and fishing gears employed), and the conflicts such activities may induce vis-à-vis existing local fishing communities. We conclude by highlighting potentially fruitful ways in which these issues might be addressed, most notably via the creation of regional property rights for the migrant fishers of the region. Moreover, as a growing body of research is showing that climate change is impacting upon the distribution of fish stocks (O'Brien et al. 2000), then increased fisher migration is likely within the region and so it is important to take ex-ante action to address what could become an even more acute problem for the regional nation states, and the populations of migrant and local fishers alike.

\section{Acknowledgements}

This article presents some of the findings of a project entitled «Strengthening of regional capabilities for the management of West African fisheries » (RECARGAO) conducted by IUCN West Africa and the Sub-Regional Commission for Fisheries (SRCF) as part to the Regional Programme for Conservation of the Coastal and Marine Zone in West Africa (PRCM). The authors have also benefited from the support of the European programme of co-operation in international research ECOST (Ecosystems, Societies, Consilience, Precautionary principle: development of an assessment method of the societal cost for best fishing practices and efficient public policies). The present article does not reflect the views of IUCN or the European Commission but only those of the authors.

The map of migrations presented in this article was prepared by Vincent Turmine from CEMARE, University of Portsmouth, UK.

\section{Endnotes}

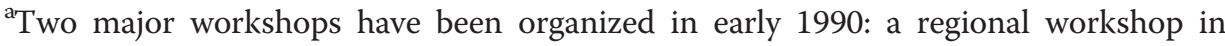
Accra (Ghana) in November 1990, precisely on the migration of small-scale fishers in West African region and host by FAO (Haakonsen and Diaw 1991) and a seminar organized by the Norwegian Cooperation in Bergen (Norway) in 1993 on the small-scale 
fisheries in West Africa and perspectives from the social sciences (Chauveau et al. 2000).

b For further information on the history of navigation and fisheries in West Africa from the 15th century, see Chauveau (1986).

Received: 24 April 2012 Revised: 24 April 2012 Accepted: 6 June 2012 Published: 6 June 2012

\section{References}

Aburto, J., M. Thiel, and W. Stotz. 2009. Allocation of effort in artisanal fisheries: the importance of migration and temporary fishing camps. Ocean \& Coastal Management 52(12): 646-654.

Bakhayokho, M., and M. Kébé. 1991. Réactions des pêcheurs face aux variations d'abondance et de disponibilité des ressources: approche méthodologique. In La Recherche Face à la Pêche Artisanale, Symposium International, ed. J.R. Durand, J. Lemalle, and J. Weber, 2:943-955. France: ORSTOM.

Binet, J. 1973. Les populations côtières d'Afrique de l'Ouest. Ethnologie Régionale I.

Binet, T. 2008. Fishing for Coherence in West Africa: Policy Coherence in the Fisheries Sector in Seven West African Countries. Paris: OECDC publication.

Binet, T., and P. Failler. 2011. Rapport préliminaire, Quantification des phénomènes migratoires des pêcheurs artisans en Afrique de l'Ouest, rapport UICN. Sénégal (forthcoming): Dakar.

Bremner, J., and J. Perez. 2002. A case study of human migration and the sea cucumber crisis in the Galapagos Islands. AMBIO: A Journal of the Human Environment 31(4): 306-310.

Cassels, S. 2006. 2006 When are Migrants "Good" or "Bad" for the Environment? Panel Contribution to the PERN Cyberseminar on Rural Household Micro-Demographics, Livelihoods, and the. April: Environment.

Chaboud, C., and M. Kébé. 1991. Les migrations de pêche maritime au Sénégal: essai d'approche quantitative. In, ed. J. M. Haakonsen and C. Diaw, 56-77 Norway: Migrations des Pêcheurs en Afrique de I'Ouest. dipa, Cotonou, fao, danida.

Chauveau, J.P. 1983. Bibliographie historique du littoral sénégambien et de la pêche maritime (milieu du XVème-début du XXème siècle), Thiaroye, CRODT/ISRA, « document scientifique ». 92: 72.

Chauveau, J.P. 1986. Une histoire maritime africaine est-elle possible? Historiographie et histoire de la navigation et de la pêche africaine à la Côte Occidentale depuis le $15^{e}$ siècle. Cahiers d'Etudes Africaines (101/102): 173-236.

Chauveau, J.P. 1991. Géographie historique des migrations de pêche dans la zone COPACE (fin XIXème siècle - années 1980). In, ed. J.M. Haakonsen and C. Diaw, 13-39 Norway: Migrations des Pêcheurs en Afrique de I'Ouest dipa, Cotonou, fao, danida.

Chauveau, J.P., E. Jul-Larsen, and C. Chaboud. 2000. Les Pêches Piroguières en Afrique de l'Ouest: Pouvoirs, Mobilités, Marchés. Karthala: $\mathrm{cmi}$ - ird.

Cinner, J.E. 2009. Migration and coastal resource use in Papua New Guinea. Ocean \& Coastal Management 52(8): $411-$ 416.

Cinner, J.E., and Ö. Bodin. 2010. Livelihood diversification in tropical coastal communities: a network-based approach to analyzing 'livelihood landscapes'. Cormier-Salem: PLoS one.

Cinner, J.E., T.M. Daw, and T.R. McClanahan. 2009. Socioeconomic factors that affect artisanal fishers' readiness to exit a declining fishery. Conservation Biology 23: 124-130.

Cormier-Salem, M.C. 1995. Paysans-pêcheurs du terroir et marins-pêcheurs du parcours. Les géographes et l'espace aquatique. L'Espace Géographique 1: 46-59.

Cormier-Salem, M.C. 2000. Appropriation des ressources, enjeu foncier et espace halieutique sur le littoral ouest-africain. In Les Pêches Piroguières en Afrique de l'Ouest: Pouvoirs, Mobilités, Marchés, ed. J.P. Chauveau, E. Jul-Larsen, and C. Chaboud, 205-229. Karthala: cmi - ird.

Costello, C.J., and D. Kaffine. 2008. Natural resource use with limited-tenure property rights. Journal of Environmental Economics and Management 55(1): 20-36.

Coulthard, S. 2008. Adapting to environmental changes in artisanal fisheries - insights from a south Indian lagoon. Global Environmental Change 18(3): 479-489.

Cripps, G. 2009. Understanding migration amongst the traditional fishers of West Madagascar. Blue Ventures Conservation Report for ReCoMaP.

Crona, B., and S. Rosendo. 2011. Outside the law? Analyzing policy gaps in addressing fishers' migrations in East Africa. Marine Policy 35: 379-388.

Dahou, T. 2008. L"itinérance" des Sereer Niominka. De l'international au local? In Le Sénégal des migrations, ed. M.-C Diop, 321-342. Paris: Karthala onu habitat et Crepos.

Dahou, K., and M. Deme. 2002. Accords de Pêche UE-Sénégal et Commerce International: respect des réglementations internationales, gestion durable des ressources et sécurité alimentaire. Dakar: Enda.

Deme, M., and M.D. Barry. 2005. Stratégies et tactiques des pêcheurs artisans sénégalais: cas des migrations. FAO/ CRODT.

Edwards, F. 2005. Ownership of multi-attribute fishery resources in large marine ecosystems. In large marine ecosystems, ed. T.M. Hennessey and J.G. Sutinen, 13:137-154.

Failler, P., and D. Gascuel. 2008. Over-exploitation in West Africa's richest zones. African report 12: 28

Failler, P., G. van de Walle, M. Deme, A. Diop, D. Balbé D, A.D. Dia, and A. Bakalakiba. 2009. Les aires protégées estuariennes, côtières et marines (APECM) en Afrique de l'Ouest: des réservoirs de ressources aquatiques en sursis. Revue Africaine des Affaires Maritimes et des Transports 1: 43-50.

Gruvel, A. 1908. Les pêcheries des côtes du Sénégal et des rivières du sud. paris: Challamel.

Haakonsen, J.M. 1991. The Role of migrating fishermen in West Africa: what we know and what we still need to learn. In La Recherche Face à la Pêche Artisanale, Symposium International, ed. J.R. Durand, J. Lemalle, and J. Weber, 709715. France: ORSTOM 
Haakonsen, J.M., and C. Diaw (eds.). 1991. Migrations des Pêcheurs en Afrique de I'Ouest. Norway: DIPA, Cotonou, fao, danida.

Jorion, P. 1988. Going out or staying home: seasonal movements and migration strategies among Xwla and Anlo-Ewe fishermen. Maritime Anthropological Studies 1(2): 129-155.

Kébé, M. 1993. Principales Mutations de la Pêche Maritime Sénégalaise. In L'évaluation des Ressources Exploitables par la Pêche Artisanale Sénégalaise, ed. M.T. Barry-Gérard, T. Diouf, and A. Fonteneau, 43-58. Dakar: ORSTOM.

Kramer, R.A., S.M.H. Simanjuntak, and C. Liese. 2002. Migration and fishing in Indonesian coastal villages. AMBIO: A Journal of the Human Environment 31(4): 367-372.

Laloë, F. 2007. Modeling sustainability: from applied to involved modeling. Social Science Information 46(1): 87-107.

Mathew, S. 2010. Food and Agricultur Oranization Workshop: child labour in fisheries and aquaculture; children's work and child labour in fisheries, 14 to 16 April 2010. Rome: International Collective in Support of fishworkers.

Monnereau, I., V. Ruiz, and R. Pollnac. 2010. Fishers' job satisfaction in the Caribbean, Etudes Caribéennes.

Nguyen Van Chi-Bonnardel, R. 1980. L'essor de l'économie de pêche artisanale et ses conséquences sur le littoral sénégalais. Cahiers d'études africaines. 20(79): 255-304.

Njock, J.C., and L. Westlund. 2010. Migration, resource management and global change: Experiences from fishing communities in West and Central Africa. Marine Policy 34(4): 752-760.

O'Brien, C.M., C.J. Fox, B. Planque, and J. Casey. 2000. Fisheries: climate variability and North Sea cod. Nature 404: 142.

Odotei, I. 1991. Migrations des pêcheurs Fante. In Migrations des Pêcheurs en Afrique de l'Ouest. DIPA, Cotonou, ed. J.M. Haakonsen and C. Diaw, 182-194. Norway: FAO, DANIDA.

Overa, R. 2000. Institutions, mobility and resilience in the Fante migratory fisheries of West Africa. Population, Consumption and Environment Initiative (PCE) Programme on Global Security and Sustainability, The MacArthur Foundation, 38. Bergen: Chr. Michelsen Institute.

Pomeroy, R.S., and F. Berkes. 1997. Two to tango: the role of government in fisheries co-management. Marine Policy 21 (5): $465-480$.

Randall, S. 2005. Review of literature on fishing migration in West Africa - from a demographic perspective: Sustainable Fisheries Livelihoods Programme, FAO and DFID.

Sall, A. 2007. Loss of Bio-Diversity: Representation and Valuation Processes of Fishing Communities. Social Science Information 46(1): 153-187.

Sall, A., and P. Morand. 2008. Pêche artisanale et émigration des jeunes africains par voie piroguière. Politique Africaine 109: 32-42.

Sharp, R. 1994. Senegal: a state of change, Oxfam country profile

Suhrke, A. 1992. 1992 Environmental degradation, migration and conflict. Washington: Paper presented at the Brookings Institutions.

Tricart, J. 1993. À propos des changements de climat récents en Afrique de l'Ouest. Journal des africanistes 63(1): 73-81.

Trouillet, B., T. Guineberteau, M. Bernardon, and S. Le Roux. 2011. Key challenges for maritime governance in West Africa: Fishery-based lessons from Guinea and Mauritania. Marine Policy 35(2): 155-162.

Warner, K. 2010. Global environmental change and migration: Governance challenges. Global Environmental Change 20 (3): 402-413.

doi:10.1186/2212-9790-11-1

Cite this article as: Binet et al: Migration of Senegalese fishers: a case for regional approach to management.

Maritime Studies 2012 11:1.

\section{Submit your manuscript to a SpringerOpen ${ }^{0}$ journal and benefit from:}

- Convenient online submission

- Rigorous peer review

- Immediate publication on acceptance

- Open access: articles freely available online

- High visibility within the field

Retaining the copyright to your article

Submit your next manuscript at $\boldsymbol{\nabla}$ springeropen.com 